\title{
APSA Names Research Grant Winners, Assesses Program's Impact
}

Earlier this summer, APSA awarded research grants to 16 scholars for projects as diverse as studying school reform in Cleveland and describing the role women play in local governance in Senegal. A complete list of grant recipients and their research topics appears in the accompanying box.

\section{Program Background}

The Research Grant Program was established in 1984 to make research resources more readily available for independent scholars and for political scientists at institutions without large research budgets. The principal investigator must be an APSA member and a political science faculty member at a college or university that does not grant a Ph.D. in political science or an independent scholar. Proposals must specify a research design, how the project relates to previous research developments, and how it contributes to scholarship within the field. Individuals may receive nonrenewable grants up to $\$ 1500$.

\section{Program Profile}

During the spring of 1999 , APSA's staff studied the value added to research from APSA funding and the caliber of work produced by the grant recipients by surveying recipients and applicants who did not receive grants over the last five years. The findings of the study illustrate that the grant program directly contributes to the promotion of scholarly research and communication, diversification of the profession, and to the quality of teaching.

One significant indicator of the program's contribution to scholarly research is that publications are gen- erated as a direct result of the research grants. Over the past five years, funded proposals have resulted in a total of forty-two publications: 15 books and 27 journal articles (see Table 1). As Denise Scheberle, a 1995 grant recipient confirmed, "The grant was instrumental in allowing me to do research that resulted in a book published by Georgetown University Press .... It's led to some really valuable experiences for me." APSA grants also resulted in 66 presentations at regional and national conferences between 1995 and 1999 (see Table 2). A second indicator that projects supported with APSA funds were more likely to be productive than those proposals APSA did not fund is that APSA-funded projects mere frequently produced peer-reviewed publications (journal articles, book chapters, and conference presentations) than did nonAPSA-funded projects.

The program is designed to aid independent scholars and faculty members at schools that do not grant a Ph.D. in political science. Open-ended responses suggest more specifically how the grants have assisted this group. John Hickman, a 1995 grant recipient, noted, "The program is a great boon to faculty who struggle to contribute to the discipline in small four-year institu-

TABLE 1
Publications Resulting from
$\begin{aligned} & \text { APSA-Funded Grant } \\
& \text { Proposals, }\end{aligned}$
\begin{tabular}{lcr} 
& \\
\hline Year & Books & Articles \\
\hline 1995 & 3 & 5 \\
1996 & 4 & 6 \\
1997 & 4 & 12 \\
1998 & 4 & 4 \\
\hline
\end{tabular}

tions." As Kerstin Haumann, a 1997 grantee remarked, "The grant allowed me to complete a concrete research project, but also spurred my interest in an area of research that I probably would not have pursued otherwise. I have been able to successfully apply for another grant that allows me to maintain the research in that area." The study indicates that over the course of the past five years $53.5 \%$ of the grant winners received additional funding from other sources.

According to the survey, the research opportunity afforded by the grants has led some recipients to collect and produce materials they can use in their classrooms. Grantees responding to a follow-up survey, agreed that their research contributed to their teaching. Kerstin Hamann noted, "I have used my Publius articles in my graduate comparative politics seminar. I have also incorporated my newly gained knowledge about regional party development in my undergraduate Western European politics course." In addition, many recipients report benefits for their students, as the grant research can also provide a hands-on opportunity for undergraduates and graduates. Students have coauthored final reports and served as research assistants.

\section{TABLE 2}

Conference Presentation Resulting from APSAFunded Grant Proposals

\begin{tabular}{cc}
\hline Year & Presentations \\
\hline 1995 & 12 \\
1996 & 14 \\
1997 & 17 \\
1998 & 15 \\
1999 & 8 \\
\hline
\end{tabular}




\section{Small Research Grant Recipients}

Richard Braunstein, "Practicing Democracy: Initiative and Referendum Voting in the Late 20th Century"

Stefanie Chambers, "The Politics of School Reform: The Impact of Mayoral Control in Chicago and Cleveland"

Nancy E. Crowe, "Decision Making on the U.S. Courts of Appeals"

Steven Daniels and Carolyn Daniels, "Paradigms of Domestic Policy: Crisis Decision Making during Hurricane Andrew"

Mitchel Gerber, "A Critical Reinterpretation of the Levellers' and Thomas Hobbes' Political Thought: A Communitarian and Classical Republican Political Philosophy"

Kim Geron, "Returning Benefits: Asian Pacific American and Latino Municipal Officials and Resource Distribution to Ethnic Communities"

John Hickman, "Candidate Preference Voting under Proportional Representation and Ethnic Mobilization in the Sri Lankan National Assembly"

Janis Ikstens, "Party Finance in South Eastern Europe and the Baltic Countries"

Philip Mauceri, "Executives, Parties, and Constitutional Reform: The Case of Peru"

David Niven, "Partisan Bias in the Media: Evidence from an Objective Comparison"

Amy Patterson, "The Impact of Senegal's Decentralization on Women in Local Governance"

Saadia Pekkanen, "The WTO and National Courts: Explaining the Judicial Reluctance to Apply International Legal Rules in Japan"

Matthew Potoski, "Political and Managerial Strategies for Improving Bureaucratic Responsiveness: Investigating State Air Pollution Control Programs"

Samory Rashid, "Islamic Threat in America? What Americans Do Not Know About Islam in the United States"

Earl Sheridan, "Race and the Rhetoric of Reaction"

J. Matthew Wilson, "Assessing the Limits of Representation: Issue Agreement between Citizens and the Legislators"
APSA Announces Grants to Political Science Departments to Participate in a Preparing Future Faculty Project

APSA is pleased to announce that four political science Ph.D. departments and their partnering institutions will receive two-year, $\$ 20,000$ grants to participate in "Shaping the Preparation of Future Social Science and Humanities Faculty: A Preparing Future Faculty Project." APSA is one of six social science and humanities professional societies participating in this project sponsored by the Council of Graduate Schools (CGS) and the American Association of Colleges and Universities (AAC\&U).

Faculty in the four departments will collaborate with faculty in political science departments in a combination of nondoctoral universities, colleges, and community colleges to provide professional preparation for academic careers to advanced doctoral candidates. The Ph.D. departments receiving awards and their partner departments are:

\section{University of Colorado} Departmental Representatives

Susan Clarke (Project Contact), Steve Chan, Sean Evans, Sam Fitch, Rodney Hero, Adrian Hull

\section{Partnering Institutions}

Colorado University, Denver (contact: Tony Robinson); Metro State College (contact: Oneida Meranto); San Jose State College (contact: Terry Christensen); Stanford University (contact: Luis Fraga); United States Air Force Academy (contact: Mark Gose)

\section{Howard University Departmental Representatives}

Alvin Thornton (Project Contact), Michael Frazier, Joseph P. McCormick, Marilyn Lashley, Lorenzo Morris, Babalola Cole, Morris Levitt, Charles Harris, Kevin Glasper, Carlin Sims

Partnering Institutions

Bowie State University (contact: Abdul K. Bangura); Catholic Uni- 